\title{
Kontribusi Beras Siger Dalam Pola Konsumsi Pangan Rumah Tangga Konsumen Beras Siger Di Provinsi Lampung
}

\section{Beras Siger Contribution For Food Consumption Pattern of Household Beras Siger Consumer In Lampung Province}

\section{Wuryaningsih Dwi Sayekti ${ }^{1 *}$, Dyah Aring Hepiana Lestari ${ }^{1}$, dan Raden Hanung Ismono $^{1}$}

${ }^{1}$ Universitas Lampung / Jurusan Agribisnis Fakultas Pertanian

*E-mail : sayekti_wur@yahoo.co.id

\begin{abstract}
The objective of this research were to investigate: (a) the consumption pattern of beras siger, (b) the household consumption pattern (Diserable Dietary Pattern /Pola Pangan Harapan $/ P P H)$, and (c) the contribution of beras siger to household energy adequacy of beras siger consumer. This research was conducted at Metro City, South Lampung Regency, and Tulang Bawang Regency used survey method. The research population was beras siger consumer of Mekar Sari Agroindustry (Metro), Siti Hawa Agroindustry (South Lampung), and Toga Sari (Tulang Bawang). There were 25 household, 19 household, and 30 household from Mekar Sari, Siti Hawa, and Toga Sari Agroindustry respectively were taken by quota sampling. Data collection were carried out on May - August 2016 by interview while food consumption data collected by recall method. The method of analysis in this research was descriptive statistic. The result showed that: $(a)$ the average of beras siger consumption of beras siger consumer at Lampung Province was 228,38 gram/household/day, the buying frequency was twice per month, in general beras siger was used as substitute of main food, and beras siger consumer buying beras siger at the factory, $(b)$ the energy consumption level of consumer beras siger household were on good category with Desirable Dietary Pattern $(D D H)$ score : 73,02, and (c) the average contribution of beras siger to energy adequacy was 10,84 percent.
\end{abstract}

Keyword: beras siger, consumption pattern, $P P H$

Disubmit : 16 September 2020; Diterima: 17 November 2020; Disetujui : 26 April 2021

\section{PENDAHULUAN}

Ketahanan pangan merupakan salah satu pilar pembangunan di Indonesia. Oleh karena itu, perwujudan ketahanan pangan yang mantap merupakan agenda utama pembangunan nasional. Dalam Undang-undang Nomor 18 tahun 2012 dinyatakan bahwa salah satu cerminan tercapainya ketahanan pangan adalah kondisi terpenuhinya pangan bagi negara sampai dengan perseorangan yang cukup, baik jumlah maupun mutunya, aman, beragam, dan bergizi. Aspek kecukupan dan keberagaman pangan merupakan ciri penting dari ketahanan pangan.

Mengingat bahwa keberagaman pangan merupakan aspek ketahanan pangan, maka ketahanan pangan tidak hanya merujuk kepada pangan pokok (beras) akan tetapi pangan secara umum. Meskipun ketahanan 
pangan bukanlah ketahanan beras dan tidak sama dengan swasembada beras, namun apabila swasembada beras tercapai maka ketahanan pangan juga tercapai (Tinaprilla, 2012).

Pada tahun 1984, Indonesia sudah mampu berswasembada beras, namun kondisi tersebut tidak berjalan lama. Pada tahun-tahun berikutnya Indonesia selalu mengimpor beras. Kenyataan tersebut terjadi karena produktivitas padi di Indonesia dalam kondisi levelling off, sementara konsumsi beras masyarakat belum dapat diturunkan secara signifikan. Salah satu target Kementerian Pertanian adalah mengurangi konsumsi beras dan terigu, yang diimbangi dengan peningkatan konsumsi umbi-umbian, pangan hewani, buah-buahan dan sayuran melalui peningkatan diversifikasi pangan. Penurunan konsumsi beras tidak hanya dalam rangka mencapai swasembada beras, tetapi juga dalam rangka meningkatkan kualitas konsumsi pangan. Upaya tersebut dilakukan dengan program diversifikasi pangan (penganekaragaman pangan) yang diarahkan pada penganekaragaman pangan lokal, yang semakin ditinggalkan masyarakat. Salah satu kelompok pangan lokal tersebut adalah umbi-umbian.

Survai Sosial Ekonomi Nasional (Susenas) tahun 2018 mendapatkan bahwa konsumsi energi dari umbi-umbian sebesar 53 kkal/kapita/hari (Badan Ketahanan Pangan Kementerian Pertanian, 2019). Data tersebut menunjukkan bahwa konsumsi umbi-umbian penduduk Indonesia masih jauh dari jumlah konsumsi yang diharapkan berdasarkan PPH golongan pangan umbi-umbian, yaitu sebesar 108 gram/kapita/hari atau setara dengan $129 \mathrm{kkal} / \mathrm{kapita} / \mathrm{hari}$ pada AKE tingkat konsumsi sebesar $2.150 \mathrm{kkal} / \mathrm{kap} / \mathrm{hari}$. Kontribusi konsumsi energi dari golongan umbi-umbian terhadap AKE pada tahun 2018 hanya sebesar 2,7 persen. Nilai tersebut masih cukup jauh dari nilai kontribusi golongan umbi-umbian terhadap AKE, yaitu sebesar 6,0 persen.

Upaya percepatan diversifikasi pangan dengan pemanfaatan pangan lokal telah dimulai pemerintah sejak tahun 2009, yaitu dengan diterbitkannya Peraturan Presiden (Perpres) Nomor 22. Salah satu pangan lokal yang berperan penting dalam diversifikasi pangan di Provinsi Lampung adalah ubi kayu. Meskipun jumlah konsumsinya cenderung menurun dari tahun 2017 ke tahun 2018, namun ubi kayu merupakan jenis umbi-umbian yang memiliki angka konsumsi tertinggi dibandingkan jenis umbi-umbian lain di Provinsi Lampung, yaitu sebesar 27 gram/kapita/hari (Badan Ketahanan Pangan Kementerian Pertanian, 2019). Hal ini didukung oleh ketersediaannya yang tinggi karena Provinsi Lampung merupakan penghasil ubi kayu terbesar di Indonesia (Kementerian Pertanian, 2018). Oleh karena itu, Provinsi Lampung telah mengembangkan agroindustri pangan lokal berbahan baku ubi kayu, yaitu beras siger.

Beras siger adalah produk beras singkong yang mengadopsi proses pembuatan tiwul, tetapi dengan penampakan (bentuk yang lebih seragam, warna yang relatif lebih cerah) dan cita-rasa yang lebih baik (Hidayat et al 2015). Pengembangan beras siger dilakukan oleh Badan Ketahanan Pangan Provinsi Lampung, sehingga beras siger tersebut telah diproduksi di beberapa agroindustri yang tersebar di beberapa kabupaten dan kota di Provinsi Lampung. Sejak tahun 2012, beras siger telah diproduksi secara komersial (industri rumah tangga/kecil).

Dari sisi produksi, pengembangan beras siger berjalan dengan baik. Agroindustri beras siger di Provinsi Lampung layak diusahakan dan menguntungkan (Hidayat, 2016; Aldhariana et al, 2016; Ariesta, et al 2016; Novia et al , 2013). Namun, dari sisi konsumsi perlu mendapat perhatian karena konsumsi pangan terkait dengan kebiasaan yang tidak dapat diubah dalam waktu singkat. Perbedaan kebiasaan akan menentukan pola konsumsi pangan seseorang. Oleh karena itu, penelitian ini akan melihat pola konsumsi pangan rumah tangga pada dua kabupaten dan satu kota di Provinsi Lampung yang telah mengembangkan beras siger, yaitu Kabupaten Lampung Selatan dan Kabupaten Tulang Bawang serta Kota Metro. Adapun tujuan penelitian ini adalah mempelajari pola konsumsi beras siger dan konsumsi pangan rumah tangga serta kontribusi beras siger terhadap kecukupan energi rumah tangga konsumen beras siger. 


\section{METODE PENELITIAN}

Penelitian ini dilaksanakan di Kabupaten Lampung Selatan, Kabupaten Tulang Bawang, dan Kota Metro yang ditentukan secara sengaja dengan pertimbangan di ketiga wilayah tersebut sedang dikembangkan agroindustri beras siger oleh Badan Ketahanan Pangan setempat.

Penelitian dilakukan pada bulan Mei-Agustus 2016. Metode penelitian yang digunakan adalah survai dengan jumlah sampel masing-masing 19 rumah tangga di Kabupaten Lampung Selatan, 30 rumah tangga di Kabupaten Tulang Bawang, dan 25 rumah tangga di Kota Metro. Jumlah sampel tersebut ditentukan dengan teknik kuota Sugiyono (2015), dimana rumah tangga sampel yang dipilih adalah rumah tangga yang membeli beras siger pada Agroindustri Siti Hawa di Lampung Selatan, Agroindustri Toga Sari di Kabupaten Tulang Bawang, dan Agroindustri Mekar Sari di Kota Metro. Responden adalah ibu rumah tangga atau anggota rumah tangga lain yang membeli beras siger.

Jenis data yang digunakan adalah data primer dan data sekunder. Data primer diperoleh dengan metode wawancara yang mencakup antara lain data jumlah dan frekuensi konsumsi beras siger, tempat membeli beras siger, serta kebiasaan konsumsi pangan anggota keluarga. Data sekunder diperoleh dari instansi terkait serta dari literatur yang mencakup anatara lain data konsumsi pangan masyarakat dan produksi beras siger. Untuk mengukur berat makanan yang dikonsumsi digunakan food model. Data konsumsi pangan diperoleh dengan metode recall 24 jam selama dua hari tidak berturut-turut (Indriani, 2015). Untuk menghitung kandungan zat gizi dan energi pangan yang dikonsumsi digunakan Daftar Komposisi Bahan Makanan (DKBM) (Kementerian Kesehatan RI, 2017).

Kontribusi energi beras siger terhadap kecukupan energi rumah tangga dihitung dengan membandingkan energi dari beras siger yang dikonsumsi rumah tangga dengan Angka Kecukupan Energi rumah tangga tersebut.

Konsumsi pangan rumah tangga dinilai baik secara kuantitas maupun kualitasnya. Penilaian secara kuantitas dilakukan dengan menghitung Tingkat Kecukupan Energi (TKE), untuk menghitung TKE digunakan rumus sebagai berikut:

TKE $=$ konsumsi energi/angka kecukupan energi $\mathrm{x} 100 \%$

Keterangan:

TKE $=$ Tingkat Kecukupan Energi

$\mathrm{AKE}$ individu $=\mathrm{BB} / \mathrm{BB}$ standar $\mathrm{x} \mathrm{AKE}$

Angka Kecukupan Energi rumah tangga yang merupakan penjumlahan dari angka kecukupan energi anggota rumah tangga (individu) yang bersangkutan. Selanjutnya, dari data konsumsi energi menurut golongan pangan yang diperoleh dilakukan penghitungan skor berdasarkan PPH, seperti terlihat pada Tabel 1.

Tabel 1. Komposisi PPH sebagai instrumen acuan perencanaan dan evaluasi konsumsi pangan

\begin{tabular}{clccccc}
\hline No. & Golongan Pangan & Gram & Kec. Energi (kkal) & Kontribusi Energi $(\%)$ & Bobot & Skor PPH Maks *) \\
\hline 1 & Padi-padian & 275 & 1000 & 50 & 0,5 & 25,0 \\
2 & Umbi-umbian & 100 & 120 & 6 & 0,5 & 2,5 \\
3 & Hewani & 150 & 240 & 12 & 2,0 & 24,0 \\
4 & Minyak dan lemak & 20 & 200 & 10 & 0,5 & 5,0 \\
5 & Buah dan biji & 10 & 60 & 3 & 0,5 & 1,0 \\
& berminyak & & & 5 & 2,0 & 10,0 \\
6 & Kacang-kacangan & 35 & 100 & 5 & 0,5 & 2,5 \\
7 & Gula & 30 & 100 & 6 & 5,0 & 30,0 \\
8 & Sayur dan buah & 250 & 60 & 3 & 0,0 & 0,0 \\
9 & Lain-lain & 0 & $\mathbf{2 0 0 0}$ & & $\mathbf{1 0 0}$ & \\
\hline
\end{tabular}


Sumber : Indriani (2015)

Keterangan : *) hasil kali kontribusi energi $(\%)$ dengan bobot.

Terlihat pada Tabel 1. bahwa skor PPH (*) adalah hasil kali kontribusi energi (\%) dengan bobot, maka skor diversifikasi konsumsi pangan dinilai dari kontribusi energi masing-masing golongan pangan terhadap konsumsi energi total dengan bobot golongan pangan yang bersangkutan dalam PPH. Skor PPH konsumsi pangan merupakan penjumlahan dari skor PPH semua golongan pangan. Analisis statistik deskriptif digunakan untuk menganalisis data.

\section{HASIL DAN PEMBAHASAN \\ Karakteristik Konsumen Beras Siger}

Sampel rumah tangga dalam penelitian ini adalah rumah tangga konsumen beras siger dari agroindustri di tiga lokasi penelitian, masing-masing adalah Agroindustri Siti Hawa di Kabupaten Lampung Selatan sebanyak 19 rumah tangga, Agroindustri Mekar Sari di Kota Metro 25 rumah tangga, dan Agroindustri Toga Sari Kabupaten Tulang Bawang 30 rumah tangga. Seluruh konsumen adalah berstatus menikah dan sebagian besar berjenis kelamin perempuan. Beberapa karakteristik yang lain bervariasi diantara tiga lokasi.

Dari sisi umur, kelompok umur 41-58 tahun mendominasi di sebagian besar lokasi, hanya di Kabupaten Tulang Bawang kelompok umur yang lebih muda mendominasi, yaitu kelompok umur 23-40 tahun. Di ketiga daerah penelitian, sebagian besar adalah suku Jawa, hanya sebagian kecil saja suku yang lain. Dilihat dari segi pendidikan, sebagian besar responden di ketiga wilayah berpendidikan SD, namun di Kota Metro terdapat konsumen yang berpendidikan relatif tinggi, yaitu lulusan S1 dan bahkan S2. Ibu rumah tangga merupakan bagian besar responden di ketiga wilayah, namun terdapat juga pekerjaan yang lain, misalnya sebagai buruh tani. Hal ini menunjukkan bahwa beras siger dikonsumsi oleh sebagian besar kelompok pekerjaan. Apabila dilihat dari kelompok pendapatan, sebagian besar konsumen beras siger berada pada kelompok pendapatan kelas bawah ( Rp 300.000,00-Rp 3.500.00,00), kenyataan tersebut hampir terjadi di ketiga daerah.

\section{Pola Konsumsi Beras Siger}

Pola pangan atau kebiasaan makan merupakan cara seseorang memilih dan memakan makanan sebagai reaksi terhadap pengaruh fisiologis, psikhologis, sosial dan budaya (Indriani, 2015). Dalam penelitian ini, pola konsumsi beras siger diartikan sebagai cara konsumen memilih dan mengkonsumsi beras siger sebagai reaksi dari pengaruh fisiologis, psikhologis, sosial dan budaya yang ditunjukkan oleh jumlah, jenis, dan frekuensi konsumsi beras siger serta tempat pembelian beras siger.

Dari hasil recall konsumsi yang dilakukan dalam penelitian ini, diperoleh bahwa dari 74 rumah tangga konsumen beras siger hanya ditemukan sebanyak 11 rumah tangga $(14,86 \%)$ yang sedang mengkonsumsi beras siger. Hal tersebut menunjukkan bahwa beras siger belum dikonsumsi sebagai kebiasaan, melainkan hanya sesekali saja dikonsumsi rumah tangga. Kenyataan ini sejalan dengan penelitian (Yusty et al ,2014) yang menemukan bahwa jenis olahan ubi kayu berupa tiwul oleh penduduk Kota Bandar Lampung tahun 2012 hanya sebesar 0,07. Hasil penelitian Sumardi (2013) di Jawa Tengah juga menemukan bahwa persentase keluarga yang mengonsumsi makanan utama berbahan ubi kayu hanya 1,42 persen.

Jumlah konsumsi beras siger dari rumah tangga yang sedang mengkonsumsi rata-rata sejumlah 225 gram/rumahtangga/hari yang berkisar antara 50 gram dengan 450 gram. Oleh karena dari hasil recall konsumsi tidak banyak ditemukan rumah tangga yang sedang mengkonsumsi beras siger, maka untuk pembahasan selanjutnya jumlah konsumsi beras siger rumah tangga digunakan data konsumsi selama satu bulan terakhir. Hasil analisis dari data jumlah dan frekuensi konsumsi beras siger dapat dilihat pada Tabel 2. 
Tabel 2. Jumlah dan frekuensi konsumsi beras siger rumah tangga di Kota Metro, Kabupaten Lampung Selatan, dan Kabupaten Tulang Bawang

\begin{tabular}{clrrrr}
\hline No. & Konsumsi Beras Siger & Metro & Lampung Selatan & Tulang Bawang & Provinsi Lampung \\
\hline 1. & Jumlah (gram/hari) & & & & \\
Rata-rata & 142,67 & 180,70 & 330,00 & 228,38 \\
Minimum & 33,33 & 33,33 & 33,33 & 33,33 \\
Maksimum & 666,67 & 666,67 & 666,67 & 666,67 \\
2. & & & & \\
Rrekuensi (x/bulan) & 4,72 & 2,68 & 4,47 & 4,09 \\
Rata-rata & 1 & 1 & 1 & 1 \\
Minimum & 16 & 6 & 28 & 28 \\
Maksimum & & & & \\
\hline
\end{tabular}

Dari Tabel 2. terlihat bahwa rata-rata konsumsi beras siger rumah tangga di Provinsi Lampung adalah sebesar 228,38 gram per rumah tangga per hari. Apabila dibandingkan diantara tiga daerah penelitian, ditemukan bahwa jumlah konsumsi beras siger di Kota Metro adalah yang paling kecil dibandingkan dengan dua daerah lainnya. Hal ini terkait dengan adanya perbedaan penggunaan beras siger tersebut. Di Kota Metro sebagian besar rumah tangga menggunakan beras siger sebagai makanan selingan (32\%), sedangkan pada dua daerah yang lainnya sebagian besar rumah tangga menggunakan beras siger sebagai pengganti nasi, masing-masing 89,47 persen di Kabupaten Lampung Selatan dan 100 persen di Kabupaten Tulang Bawang. Hasil penelitian ini ternyata berbeda dengan hasil penelitian Sumardi (2013) yang mendapatkan bahwa makanan berbahan baku singkong sebagian besar dikonsumsi sebagai makanan penyela.

Pangan lokal sumber karbohidrat, seperti singkong lebih banyak disajikan dalam bentuk kudapan atau pangan selingan, sehingga jumlah konsumsinya terbatas. Selain itu, menurut Zulkarnain (2017), minimnya pengetahuan tentang manfaat tiwul menjadikan tiwul belum begitu di nikmati oleh para konsumen, sehingga permintaannya belum maksimal. Dalam penelitian ini, justru di dua daerah penelitian (Kabupaten Lampung Selatan dan Tulang Bawang) beras siger merupakan olahan singkong yang digunakan sebagai pengganti nasi, hal ini terjadi dikarenakan kebiasaan makan dan ketersediaan pangan di rumah tangga. Rumah tangga di Kabupaten Lampung Selatan dan Tulang Bawang mengonsumsi beras siger (tiwul) karena membuat sendiri dari hasil usahatani singkong yang dimiliki. Rumah tangga hanya sesekali saja membeli beras siger dari agroindustri karena harganya yang mahal, sama dengan harga beras. Kenyataan ini sejalan dengan hasil penelitian Indiako et al (2014) yang menunjukkan bahwa petani ubi kayu di desa pelaksana Program MP3L (Desa Pancasila, Kabupaten Lampung Selatan) lebih memilih membuat tiwul sendiri dari hasil panen untuk dikonsumsi dibandingkan harus membeli beras siger karena harga tiwul dianggap terlalu tinggi.

Meskipun sebagian besar rumah tangga menggunakan beras siger sebagai pengganti nasi, namun kelengkapan (lauk) konsumsi beras siger pada umumnya tidak sama dengan nasi. Di Kabupaten Lampung Selatan dan Kabupaten Tulang Bawang sebagian besar rumah tangga menyatakan bahwa kelengkapan konsumsi beras siger berbeda dengan nasi, berbeda dengan Kota Metro dimana sebagian besar rumah tangga menyatakan bahwa kelengkapan konsumsi beras siger sama dengan nasi.

Dari Tabel 2 juga terlihat frekuensi rumah tangga dalam mengkonsumsi beras siger. Rata-rata frekuensi konsumsi beras siger oleh sebagian besar rumah tangga konsumen adalah sekitar 4 kali/bulan atau 1 kali/minggu, kecuali di Kabupaten Lampung Selatan dimana frekuensinya hanya 2 kali/bulan. Kenyataan rendahnya frekuensi konsumsi tersebut menunjukkan bahwa beras siger di Kabupaten Lampung Selatan khususnya di Desa Lebung Nala (lokasi penelitian) belum memasyarakat.

Untuk Kabupaten Tulang Bawang, rata-rata frekuensi konsumsi beras siger hasil penelitian ini adalah sebesar 4,47 kali per bulan. Hasil tersebut lebih tinggi daripada hasil penelitian Syafani et al (2015) yang mendapatkan bahwa frekuensi konsumsi tiwul masyarakat adalah antara 1-2 kali per bulan. Perbedaan ini terjadi karena Syafani et al (2015) hanya meneliti konsumsi beras siger orang yang membeli beras siger di rumah makan. Meskipun belum menjadi makanan yang biasa dimakan, namun apabila rumah tangga 
menyajikan beras siger, maka sebagian besar anggota rumah tangga akan mengkonsumsinya. Gambar 1 menunjukkan distribusi pengkonsumsi beras siger pada rumah tangga di Kota Metro, Kabupaten Lampung Selatan, dan Kabupaten Tulang Bawang.

Dari Gambar 1 terlihat bahwa di Kabupaten Tulang Bawang beras siger lebih bisa diterima oleh sebagian besar anggota rumah tangga dibandingkan dua daerah yang lain. Hal tersebut terjadi oleh karena konsumen beras siger di Tulang Bawang sebagian besar sudah terbiasa mengkonsumsi tiwul yang sama dengan beras siger, bahkan banyak diantara rumah tangga tersebut membuat sendiri beras siger tersebut. Hal demikian juga dilakukan oleh rumah tangga di Kecamatan Natar Kabupaten Lampung Selatan (Hendaris et al, 2013)

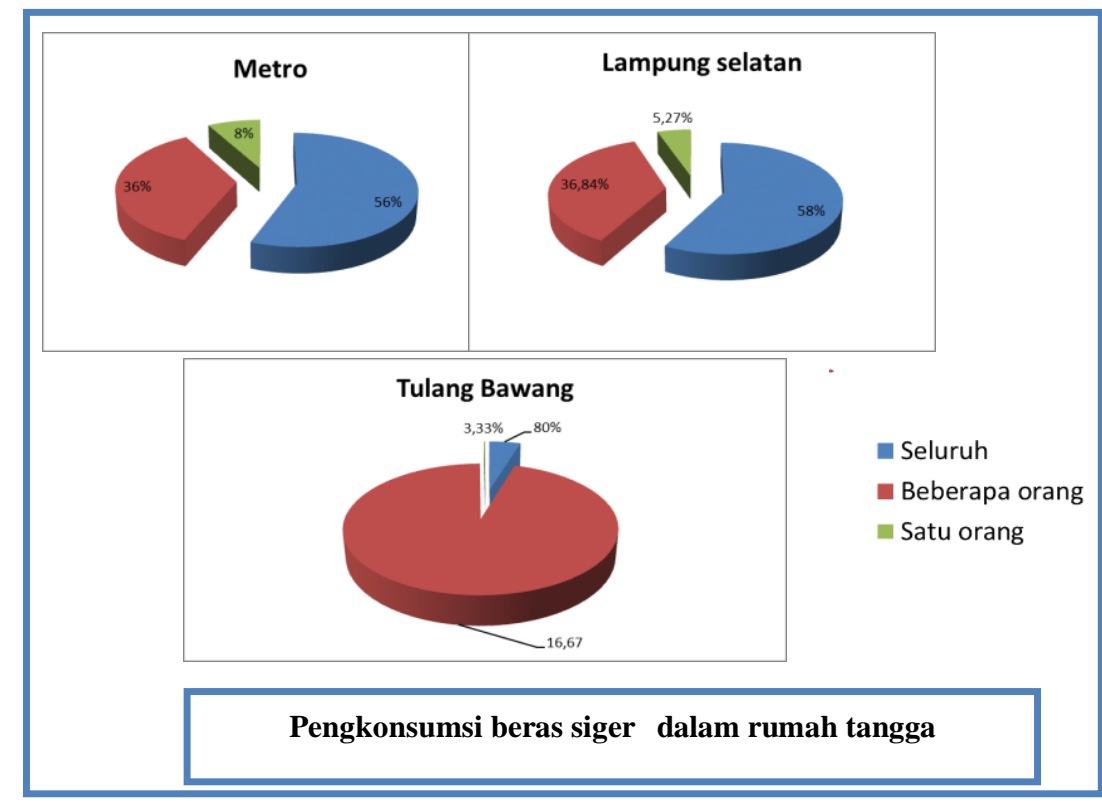

Gambar 1. Distribusi pengkonsumsi beras siger pada rumah tangga di Kota Metro, Kabupaten Lampung Selatan, dan Kabupaten Tulang Bawang.

Rumah tangga konsumen beras siger di tiga daerah penelitian hampir seluruhnya membeli beras siger di lokasi agroindustri terdekat, hanya dua konsumen di Kabupaten Lampung Selatan (10,53\%) yang membeli beras siger di pasar terdekat. Hal ini terjadi karena sebagian besar konsumen beras siger adalah rumah tangga di sekitar pabrik, selain itu juga agroindustri beras siger tidak mendistribusikan produknya ke berbagai pasar.

\section{A. Konsumsi Pangan Rumah Tangga}

Evaluasi terhadap konsumsi pangan rumah tangga dapat dilakukan secara kuantitatif dan kualitatif. Hasil penilaian kecukupan konsumsi pangan rumah tangga konsumen beras siger pada penelitian ini ditunjukkan oleh nilai TKE rumah tangga. Gambar 2. memperlihatkan nilai TKE rumah tangga konsumen beras siger Kota Metro, Kabupaten Lampung Selatan, dan Kabupaten Tulang Bawang. 


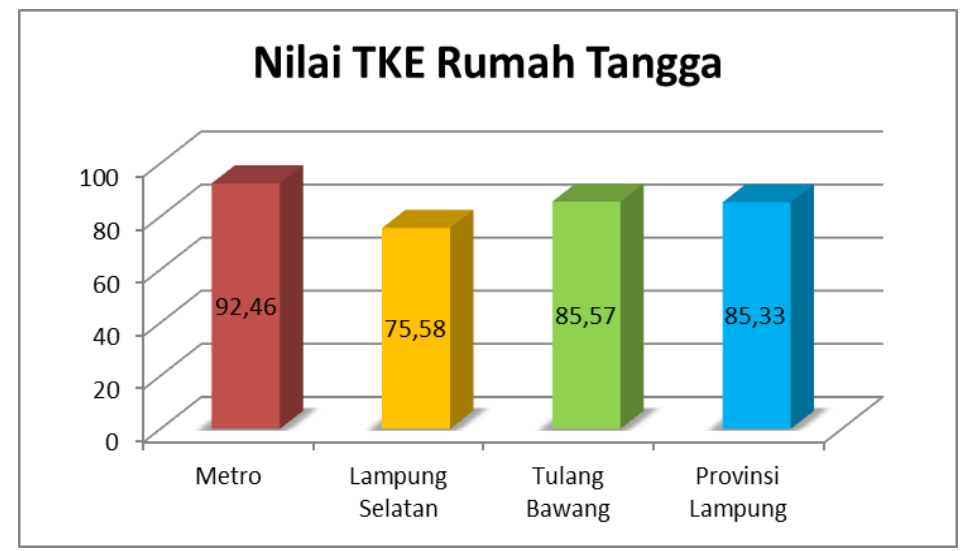

Gambar 2. Nilai TKE rumah tangga konsumen beras siger Kota Metro, Kabupaten Lampung Selatan, dan Kabupaten Tulang Bawang.

Dari Gambar 2 terlihat bahwa rata-rata TKE rumah tangga konsumen beras siger cukup tinggi, sebagian besar sudah dalam kategori cukup baik, yaitu $\geq 80$ persen Indriani, (2015), kecuali Kabupaten Lampung Selatan. Rendahnya TKE rumah tangga di Lampung Selatan diduga berkaitan dengan kondisi perekonomian di daerah tersebut, dimana pendapatan rumah tangga kosumen beras siger di Lampung Selatan lebih rendah daripada dua daerah penelitian lain. Hal ini sejalan dengan teori fungsi konsumsi yang menunjukkan bahwa terdapat hubungan besarnya konsumsi dengan pendapatan. Pendapatan yang rendah akan mempengaruhi asupan energi dari makanan.

Selain dari sisi kuantitas, konsumsi pangan rumah tangga juga dapat dinilai secara kualitas dengan indikator skor PPH. Skor PPH rumah tangga hasil penelitian ini dapat dilihat pada Gambar 3.

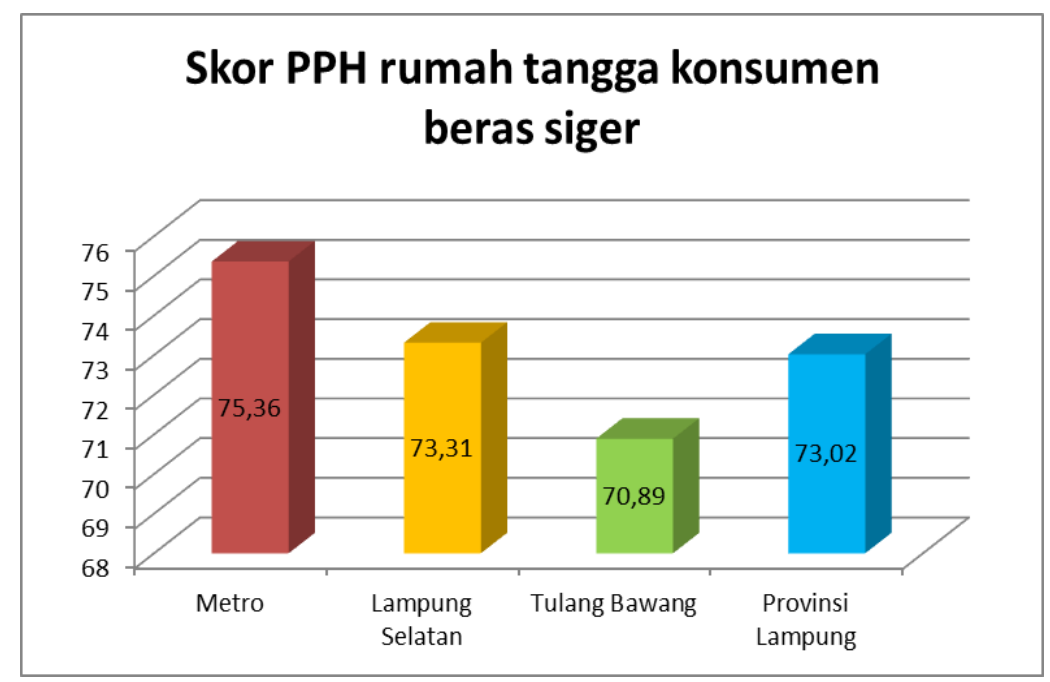

Gambar 3. Skor PPH rumah tangga konsumen beras siger di Kota Metro, Kabupaten Lampung Selatan, dan Kabupaten Tulang Bawang

Skor PPH rumah tangga konsumen beras siger di Provinsi Lampung dari hasil penelitian ini adalah sebesar 73,02. Nilai tersebut lebih rendah dari release dari Badan Ketahanan Pangan Daerah (BKPD) Provinsi Lampung, yaitu sebesar 80. Perbedaan skor dengan release dari BKPD Provinsi Lampung diduga terjadi oleh karena penelitian ini hanya pada rumah tangga konsumen beras siger, dimana sebagian adalah rumah tangga dengan tingkat pendapatan menengah ke bawah, sementara BKPD Provinsi Lampung mengukur skor PPH pada rumah tangga pada seluruh lapisan masyarakat. Skor PPH hasil penelitian ini 
hampir sama dengan skor PPH rumah tangga di kawasan rumah pangan lestari di Desa Daya Murni Kecamatan Tumijajar Kabupaten Tulang Bawang, yaitu sebesar 73,1 (Zahara and Mulyanti 2017).

\section{B. Kontribusi Beras Siger terhadap Kecukupan Energi}

Umbi-umbian merupakan salah satu kelompok pangan, merupakan salah satu kontributor terhadap konsumsi pangan seseorang atau kelompok orang (rumah tangga atau masyarakat). Beras siger merupakan salah satu jenis pangan olahan dari ubi kayu tentu juga merupakan kontributor terhadap pemenuhan energi dan zat gizi. Kontribusi energi beras siger terhadap kecukupan energi rumah tangga konsumen beras siger di Kota Metro, Kabupaten Lampung Selatan, dan Kabupaten Tulang Bawang dapat dilihat pada Gambar 4.

Dari Gambar 4 terlihat bahwa rata-rata kontribusi energi beras siger (dari recall kosumsi selama satu bulan) terhadap kecukupan energi rumah tangga di Provinsi Lampung adalah sebesar 10,84 persen. Ratarata kontribusi tersebut lebih besar dari standar PPH, yaitu sebesar 6 persen. Rata-rata kontribusi beras siger terhadap kecukupan energi rumah tangga di tiga daerah penelitian berada di atas standar skor PPH. Kontribusi energi beras siger terhadap angka kecukupan energi hasil penelitian ini lebih besar daripada hasil penelitian Syafani et al (2015) yang mendapatkan kontribusi sebesar 5,16 persen. Perbedaan tersebut terjadi karena Syafani et al (2015)hanya meneliti konsumsi tiwul (beras siger) orang yang konsumsi di rumah makan.

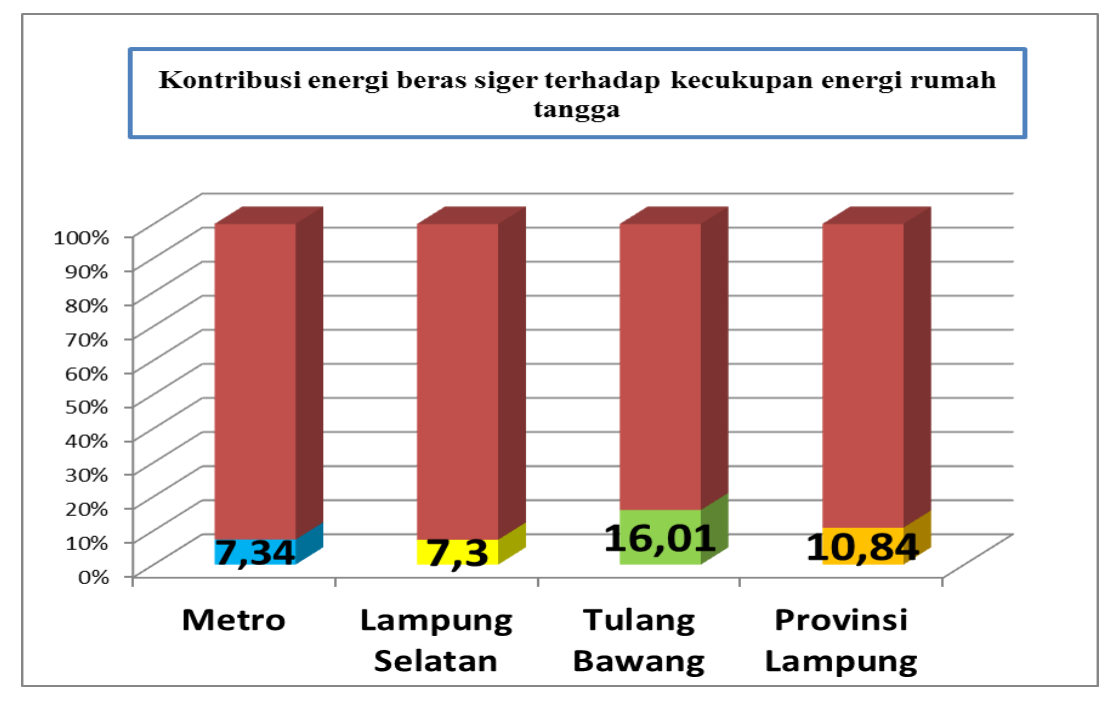

Gambar 4. Kontribusi energi beras siger terhadap kecukupan energi rumah tangga konsumen beras siger di Kota Metro, Kabupaten Lampung Selatan, dan Kabupaten Tulang Bawang

Apabila dibandingkan dengan kontribusi umbi-umbian terhadap konsumsi energi total hasil Susenas 2018 yang hanya sebesar 2,7 persen menunjukkan bahwa beras siger memiliki peran yang penting untuk meningkatkan konsumsi energi kelompok umbi-umbian. Dengan kata lain, apabila rumah tangga mengkonsumsi beras siger dengan pola seperti rumah tangga konsumen beras siger dalam penelitian ini, rumah tangga tersebut sudah mampu memenuhi kecukupan energi kelompok umbi-umbian.

\section{KESIMPULAN}

Dari hasil penelitian ini disimpulkan: (a) konsumsi beras siger rumah tangga konsumen beras siger di Provinsi Lampung rata-rata 228,38 gram per rumah tangga per hari, dengan frekuensi dua kali per bulan, sebagian besar siger dikonsumsi sebagai pensubstitusi pangan pokok, dan sebagian besar konsumen membeli beras siger di pabrik beras siger, (b) tingkat kecukupan energi rumah tangga konsumen beras siger berada 
pada kategori baik dengan skor PPH untuk Provinsi Lampung 73,02, dan (c) kontribusi beras siger terhadap kecukupan energi rata-rata sebesar 10,84 persen.

\section{DAFTAR PUSTAKA}

Aldhariana, S. F., Lestari, D. A. H. \& Ismono, R. H. . (2016). Keragaan Agroindustri Beras Siger (Kasus Di Agroindustri Toga Sari Kabupaten Tulang Bawang Dan Agroindustri Mekar Sari Kota Metro). Jiia, 4(3), 277-284.

Ariesta, W., Lestari, D. A. H., Sayekti, W. D \& Ismono R. H. (2016). Perilaku Konsumen Dan Strategi Pengembangan Agroindustri Beras Siger Tunas Baru Di Kelurahan Pinang Jaya Kemiling Kota Bandar Lampung. JIIA, 4(3), 161-170.

Badan Ketahanan Pangan Kementerian Pertanian. (2019). Direktori Perkembangan Konsumsi Pangan. Jakarta (ID).

Hendaris, T. W., Zakaria, W. A., \& Kasymir, E. (2013). Pola Konsumsi Dan Atribut-Atribut Beras Siger Yang Diinginkan Konsumen Rumah Tangga Di Kecamatan Natarkabupaten Lampung Selatan. JIIA (Jurnal Ilmu-Ilmu Agribisnis), 1(3), 232-237.

Hidayat, B. (2016). Prospek Pengembangan dan Teknologi Pengolahan Beras Siger (tiwul dan oyek yang telah dimodernisasi) (Vol. 1). Bandar Lampung (ID): Politeknik Negeri Lampung.

Hidayat, B., Akmal, S., \& Surfiana. (2015). Kajian Potensi Beras Siger (Tiwul Instan) Fortifikasi Sebagai Pangan Fungsional. Prosiding Seminar Nasional Swasembada Pangan, 2(April), 473-479.

Indiako, M., Ismono, R., \& Soelaiman, A. (2014). Studi Perbandingan Pola Alokasi Lahan, Pengeluaran Beras Dan Pola Konsumsi Pangan Antara Petani Ubi Kayu Di Desa Pelaksana Dan Non Pelaksana Program Mp3L Di Kabupaten Lampung Selatan. Jurnal Ilmu-Ilmu Agribisnis, 2(4), 331-336. https://doi.org/10.23960/jiia.v2i4.331-336

Indriani, Y. (2015). Gizi dan Pangan. Bandar Lampung (ID): CV Anugrah Utama Raharja (AURA).

Kementerian Kesehatan RI. (2017). Pedoman Metode Melengkapi Nilai Gizi Bahan Makanan pada Tabel Komposisi Pangan Indonesia. Bogor.

KEMENTERIAN PERTANIAN. (2018). Statistik Konsumsi Pangan. Indonesia.

Novia, W., Zakaria, W. A. \& Lestari, D. A. H. (2013). Analisis Nilai Tambah Dan Kelayakan Pengembangan Agroindustri Beras Siger. Jurnal Ilmu-Ilmu Agribisnis, 1(3), 210-217.

Sugiyono. (2015). Metode Penelitian Kombinasi (Mix Methods). Bandung: Alfabeta.

Sumardi. (2013). Pola Konsumsi Pangan Berbahan Ubi Kayu di Jawa Tengah. Seri Kajian Ilmiah, 1-55.

Syafani, T. S., Lestari, D. A. H., \& Sayekti, W. D. (2015). Analisis Preferensi, Pola Konsumsi, Dan Permintaan Tiwul Oleh Konsumen Rumah Makan Di Provinsi Lampung. Jiia, 3(1), 85-92.

Tinaprilla, N. (2012). Diversifikasi Pangan: Mudah tapi Sulit. Jakarta (ID): Departemen Agribisnis, FEMIPB dan PERHEPI.

Yusty, G. T, Zakaria, W. A, \& Adawiyah, R. (2014). Analisis Pola Konsumsi Ubi Kayu Dan Olahannya Pada Rumah Tangga Di Kota Bandar Lampung. Jiia, 2(2), 182-189.

Zahara, \& Mulyanti, N. (2017). Analisis Konsumsi Pangan dan Faktor Sosial Ekonomi yang Berhubungan dengan Pola Pangan Harapan (PPH) pada Model Kawasan Rumah Pangan Lestari (MKRPL) Desa 
Journal of Food System and Agribusiness

Daya Murni Kecamatan Tumijajar Kabupaten Tulang Bawang. Prosiding 1. Badan Pengkajian dan Penerapan Teknologi.

Zulkarnain, Z. (2017). Analisis Strategi Pengembangan Pemasaran Dan Nilai Tambah Tiwul Instan. Journal of Food System \& Agribusiness, 1(1), 1-11. https://doi.org/10.25181/jofsa.v1i1.79 